\title{
TậN DỤNG LỚP NHỚT TRÁI CÀ PHÊ ĐỂ NUÔI CẤY VI SINH THU NHẬN ENZYME PECTINASE LÀM TRONG RỰ̛U VANG
}

\author{
Trần Ngọc Hùng ${ }^{(1)}$ \\ (1) Trường Đại học Thủ Dầu Một \\ Ngày nhận bài 20/12/2019; Ngày gưi phản biện 05/01/2019; Chấp nhận đăng 30/01/2020 \\ Liên hệemail: hungtn@tdmu.edu.vn
}

https://doi.org/10.37550/tdmu.VJS/2020.01.011

\section{Tóm tắt}

Enzyme pectinase được ứng dụng trong nhiều lãnh vưc sản xuất khác nhau. Việc tận dụng thành phần pectin có trong trái cà phê để cảm ứng sinh pectinase không chỉ giúp tận dụng tốt nguồn phế liệu này mà còn giúp nâng cao hiệu quả quá trình chế biến cà phê theo phuơng pháp uoót. Trên môi truờng bán rắn, hiệu quả sinh tổng hơp pectinase của chủng Aspergillus niger Đ3 không cao, hoạt độ tối ưu chỉ đạt 0,88 UI/g trên môi truờng có chứa $20 \%$ vỏ cà phê sau 5 ngày nuôi cấy. Ngược lại, thành phần pectin trong lớp nhớt của trái cà phê có khả năng cảm úng Bacillus Ba 79 sinh pectinase với hiệu quả khá cao, hoạt độ enzyme tối đa đạt 2,33 UI/g sau 4 ngày nuôi cấy trên môi trương có chía $60 \%$ dịch nhớt cà phê, $16 \%$ bắp xay và $24 \%$ bã đậu nành. Chế phẩm pectinase tù Bacillus Ba 79 có khả năng làm tăng độ trong của rươu vang 41,8\% khi bổ sung với tỷ lệ 7,5 UI/ lít, trong thời gian 180 phút.

Tù khóa: aspergillus niger, chế biến cà phê, dung dịch lớp nhót, enzyme pectinase

\section{Abstract}

\section{USING THE VISCOUS LAYER OF COFFEE FRUIT TO CULTURE MICROORGANISM SO AS TO RECIEVE ENZYME PECTINASE FOR INSREASING TRANSPARENCE OF WINE}

Enzyme pectinase are applied in many different production areas. Taking advantage of the pectin content in coffee fruit to induce microorganism biosynthesis pectinase does not only help to reuse of this waste, but also to improve the efficiency of the coffee processing by soaked method. On semi-solid medium, efficiency of pectinase biosynthesis of Aspergillus niger Đ3 strain was not high, the maximum activity was only $0.88 \mathrm{UI} / g \mathrm{r}$ on medium containing 20\% coffee pulp after 5 days culture. Whereas, the pectin content in the viscous layer of coffee fruit is able to induce Bacillus BS79 biosynthesis the pectinase effectively, with the enzyme maximum activity of $2.33 \mathrm{UL} / \mathrm{gr}$ after 4 days of culture on $60 \%$ of the viscous solution, $16 \%$ grinded corn and $24 \%$ soybean residue. The pectinase product from Bacillus Ba 79 is capable of increasing transparence of wine $41.8 \%$ at the ratio of 7.5 UI/l for 180 minutes. 


\section{1. Đặt vấn đề}

Pectinase là enzyme phân giải pectin, được sử dụng rộng rãi trong công nghiệp chế biến thực phẩm, tách rời các sợi thực vật, xử lý nước thải, lọc dầu thực vật, lên men trà và cà phê, tẩy trắng giấy. Các enzyme pectinase thường giúp cho việc chiết xuất, lọc và tinh lọc nước quả và nước giải khát được dễ dàng cũng như làm tăng sản lượng trong sản xuất. Trong công nghệ sản xuất các loại nước trái cây và rượu vang. Người ta sử dụng enzyme pectinase để khử pectin, tránh hiện tượng bị đục và lắng cặn trong quá trình sản xuất và bảo quản. Những năm gần đây, enzyme pectinase còn được sử dụng để nâng cao khả năng bóc vỏ của tiêu; rút ngắn thời gian hoai mục của vỏ cà phê trong quá trình ủ; xử lý lớp nhớt bám trên hạt cà phê, giúp rút ngắn thời gian chế biến cà phê (Trần Thị Thanh Thuần, 2009).

Với thành phần ước tính chiếm $40-45 \%$ trọng lượng hạt cà phê, hàng năm ngành chế biến cà phê thải ra khoảng 765 ngàn tấn vỏ. Con số không nhỏ này đòi hỏi phải có biện pháp xử lý thích hợp, đảm bảo vệ sinh môi trường. Trên thế giới, người ta cũng đã tiến hành nghiên cứu tận dụng và xử lý vỏ cà phê như tận dụng làm thức ăn gia súc và tách một số chất. Trong nước, vỏ cà phê chủ yếu được các hộ nông dân sử dụng để ủ hoai làm phân hữu cơ, bón trở lại cho vườn cà phê. Gần đây, một số đề tài nghiên cứu cũng thử nghiệm sử dụng nguồn phế thải này để làm rượu vang, làm phân vi sinh từ vỏ cà phê hoặc tách chiết pectin. Pectin là thành phần chủ yếu của lớp nhớt, chiếm từ 20 $23 \%$ tổng trọng lượng khô của trái cá phê. Trong lớp vỏ, hàm lượng pectin cũng lên đến 17\% (Nguyễn Đức Lượng, 2010). Việc sử dụng nguồn pectin dồi dào trong vỏ trái cà phê để cảm ứng sinh enzyme pectinase từ các vi sinh vật không những giúp tận dụng tốt nguồn phế liệu nông nghiệp này mà còn nâng cao hiệu quả quá trình chế biến cà phê theo phương pháp voơt. Trên cơ sở đó chúng tôi thực hiện đề tài "Tận dụng lớp nhớt trái cà phê để nuôi cấy vi sinh thu nhận enzyme pectinase nhằm làm trong rượu vang".

\section{Vật liệu và phương pháp}

\section{Vật liệu:}

- Trái cà phê: thuộc giống cà phê vối (Robusta) lấy từ vườn của hộ dân thuộc xã Liên Đầm, huyện Di Linh, tỉnh Lâm Đồng.

- Vỏ cà phê khô: trái cà phê tươi được xay xát để tách phần vỏ, sấy khô vỏ cho đến khi độ ẩm còn khoảng $10 \%$.

- Dịch nhớt: trái cà phê tươi sau khi xay xát tách phần vỏ được ngâm nước với tỷ lệ $1: 1(\mathrm{v} / \mathrm{v})$, khuấy đều trong 24 giờ để tách hết lớp nhớt bám trên hạt cà phê

- Rượu vang: được sản xuất từ giống nho Sawignon blanc. Rượu vang được giữ ở nhiệt độ phòng $\left(\sim 30^{\circ} \mathrm{C}\right)$, sau 2 năm kể từ ngày đóng chai được sử dụng để thử nghiệm 
- Các chủng Bacillus sp.: Ba 01, Ba 02, Ba 03, Ba 04, Ba 05, Ba 41 và Ba 79 được phân lập từ môi trường đất, do phòng thí nghiệm vi sinh ứng dụng, trường đại học Thủ Dầu Một cung cấp.

- Các chủng Aspergillus niger: Asp T1, Asp T4, Asp Đ2 và Asp Đ3 được phân lập từ các loại vỏ cam, vỏ chanh, cùi bưởi, do phòng thí nghiệm vi sinh ứng dụng, trường đại học Thủ Dầu Một cung cấp.

- Môi trường định tính khả năng sinh pectinase cho vi khuẩn (MT1): pectin 0,5g; glucose $0,05 \mathrm{~g}$; pepton $0,2 \mathrm{~g} ; \mathrm{NaCl} 3 \mathrm{~g} ; \mathrm{K}_{2} \mathrm{HPO}_{4} 1,5 \mathrm{~g} ; \mathrm{KH}_{2} \mathrm{PO}_{4} 1,5 \mathrm{~g}$; agar $20 \mathrm{~g}$; nước cất vừa đủ 1 lít.

- Môi trường định tính khả năng sinh pectinase cho nấm mốc (MT2): pectin 0,5 $\mathrm{g}$; agar 20g; nước cất vừa đủ 1 lít.

- Môi trường tăng sinh vi khuẩn Bacillus sp. (MT3): glucose 20g; pepton $10 \mathrm{~g}$; nước giá đậu $10 \%$ vừa đủ 1 lít

- Môi trường bán rắn nuôi cấy nấm mốc sinh pectinase: cám $75 \%$; trấu $16 \%$; chất cảm ứng 8\%; $\left(\mathrm{NH}_{4}\right)_{2} \mathrm{SO}_{4} 1 \%$ (Ashfaq K., 2012; Tivkaa A., 2012).

\section{Phuơng pháp nghiên cứu:}

Định tính khả năng sinh enzyme pectinase trên môi trương thạch đĩa: Các chủng vi sinh vật từ các ống thạch nghiêng được cấy vào môi trường định tính tương ứng; các chủng Bacillus sp. cấy trên môi trường $\mathrm{MT1}$; các chủng Aspergillus niger cấy trên môi trường MT2. Ủ ở nhiệt độ phòng $\left(30^{\circ} \mathrm{C}\right)$, sau 3 ngày, xác định vòng phân giải pectin của các chủng với thuốc thử lugon (Lê thị Thu Trang, 2011).

Định lương đường khư theo phương pháp Miller: Trộn đều $0,5 \mathrm{ml}$ dịch lọc với 0,5 $\mathrm{mL}$ thuốc thử $\mathrm{DNS}$, đun sôi cách thủy trong 5 phút, thêm nước cất cho đủ $5 \mathrm{ml}$ và so màu ở bước sóng $540 \mathrm{~nm}$. Hàm lượng đường khử trong dung dịch được xác định thông qua đường chuẩn của đường glucose (Nguyễn Văn Mùi, 2007).

Xác định hoạt tính enzyme pectinase bằng phuơng pháp định luợng đuoòng khư: Trộn đều $0,5 \mathrm{ml}$ dung dịch enzyme pectinase với $0,5 \mathrm{ml}$ dung dịch pectin $0,5 \%$ pha trong đệm acetate $\mathrm{pH} 5.0$, ủ ở $40^{\circ} \mathrm{C}$ trong 60 phút. Thêm $1 \mathrm{ml}$ thuốc thử DNS, đun sôi cách thủy trong 5 phút và so màu ở bước sóng 540nm (Lâm Thị Kim Châu, 2004). Một đơn vị hoạt độ (UI) enzyme pectinase là lượng enzyme tối thiểu trong điều kiện chuẩn $\left(40^{\circ} \mathrm{C}, \mathrm{pH} 5 \ldots\right)$ thủy phân pectin trong 1 phút tạo ra $1 \mu$ mol D-galacturonic acid.

Tách chiết pectin: Vỏ trái cà phê và dịch nhớt được ngâm trong thời gian 1 giờ với dung dịch acid citric $5 \%$ ở nhiệt độ $85^{\circ} \mathrm{C}$, ly tâm tách dịch chiết, để nguội. Dùng cồn $96^{\circ}$ để kết tủa pectin trong dịch chiết, tiến hành lọc và thu kết tủa pectin thô bằng giấy lọc sấy khô đã biết trước khối lượng không đổi. Cuối cùng, rửa kết tủa pectin thô bằng cồn lạnh nhiều lần và sấy khô ở $50^{\circ} \mathrm{C}$ đến trọng lượng không đổi. Kết tủa pectin thô sau khi sấy được để nguội và xác định khối lượng bằng cân phân tích (Ermias Grim, 2016). 
Xư lý thống kê: Các thử nghiệm trong phòng thí nghiệm được tiến hành lặp lại ít nhất 3 lần và phân tích $\mathrm{ANOVA}$ bằng phần mềm Stagraphic Centurion XV.

\section{Bố trí thí nghiệm:}

Đánh giá một số thành phần sinh hóa của vỏ trái cà phê: Vỏ cà phê khô được xay nhuyễn được sử dụng để đánh giá một số thành phần sinh hóa như hàm lượng pectin, đường khử, đạm tổng số, $\mathrm{pH} 10 \%$ trong nước và độ ẩm. Kết quả đánh giá các chỉ tiêu này là cơ sở để nuôi cấy các chủng vi sinh vật sinh tổng hợp enzyme pectinase.

Định tính khả năng sinh pectinase của các chủng vi sinh trên môi trường thạch đĩa: Các chủng Bacillus và Aspergillus niger từ các ống thạch nghiêng được cấy lên các môi trường định tính, sau khoảng thời gian 3 ngày, xác định đường kính vòng phân giải pectin với thuốc thử lugon. Vùng có hoạt tính của enzyme pectinase sẽ trong suốt, không hiện màu nâu đỏ với thước thử lugon. $\mathrm{D}(\mathrm{mm})=\mathrm{V}-\mathrm{v}$. Với $\mathrm{V}$ : đường kính vùng hoạt tính của enzyme pectinase; $v$ : đường kính vòng tăng trưởng của chủng vi sinh vật.

Đánh giá hàm lương một số thành phần sinh hóa của vỏ trái cà phê: Trái cà phê chín đỏ sau khi thu hái được rửa sạch, để khô tự nhiên; tách lớp vỏ ngoài và dịch nhớt để xác định hàm lượng một số thành phần sinh hóa như: hàm lượng pectin; hàm lượng đạm tổng số, hàm lượng đường khử, $\mathrm{pH}$, độ ẩm.

Khả năng cảm úng Bacillus sinh pectinase của vỏ cà phê khô: Các chủng Bacillus sp. được tăng sinh trên môi trường MT3, sau 24 giờ, cấy $2 \mathrm{ml}$ giống vào các bình tam giác chứa $75 \mathrm{~g}$ môi trường bán rắn có thành phần dịch nhớt cà phê $60 \%$; bắp xay và bã đậu nành $40 \%$ (bảng 1 ). Sau thời gian ủ 3 ngày ở nhiệt độ phòng $\left(30^{\circ} \mathrm{C}\right)$, canh trường được sấy khô ở $45^{\circ} \mathrm{C}$ và xác định hoạt tính enzyme pectinase bằng phương pháp định lượng đường khử.

Bảng 1. Thành phần môi trương nuôi cấy Bacillus sp. thu nhận pectinase

\begin{tabular}{|c|c|c|c|}
\hline Nghiệm thức & Dịch lớp nhớt (\%) & Bắp xay (\%) & Bã dậu nành (\%) \\
\hline NT1 & 60 & 28 & 12 \\
\hline NT2 & 60 & 24 & 16 \\
\hline NT3 & 60 & 20 & 20 \\
\hline NT4 & 60 & 16 & 24 \\
\hline NT5 & 60 & 12 & 28 \\
\hline
\end{tabular}

Đánh giá khả năng cảm ưng vi nấm sinh pectinase của lớp nhớt trái cà phê: Các chủng Aspergillus niger từ môi trường thạch nghiêng được cấy vào các erlen chứa $25 \mathrm{~g}$ môi trường bán rắn có thành phần cơ chất như bảng $2,\left(\mathrm{NH}_{4}\right)_{2} \mathrm{SO}_{4} 1 \%$, độ ẩm $44 \%$. Mật độ giống ban đầu khoảng $10^{7}$ bào tử/g canh trường. Ủ ở nhiệt độ phòng $\left(30^{\circ} \mathrm{C}\right)$. Sau 5 ngày, thu nhận và sấy khô cho đến khi độ ẩm còn khoảng $10 \%$. Xác định hoạt độ pectinase trong canh trường bằng phương pháp định lượng đường khử. 
Bảng 2. Thành phần môi truò̀ng nuôi cấy Aspergillus niger thu nhận pectinase

\begin{tabular}{|c|c|c|}
\hline Nghiệm thức & Cám gạo $(\boldsymbol{\%})$ & Vỏ cà phê $(\boldsymbol{\%})$ \\
\hline NT1 & 50 & 5 \\
\hline NT2 & 45 & 10 \\
\hline NT3 & 40 & 15 \\
\hline NT4 & 35 & 20 \\
\hline NT5 & 30 & 25 \\
\hline
\end{tabular}

Thủ nghiệm làm trong rựu vang của chế phẩm pectinase: Rượu vang có dung tích 750ml được để yên cho lắng trong thời gian 2 năm. Gạn phần rượu trong phía trên cho, phần rượu có chứa cặn phía dưới còn lại khoảng $150 \mathrm{ml}$. Lắc đều rượu rồi bổ sung dung dịch enzyme pectinase. Thí nghiệm bao gồm các nghiệm thức 2,5 UI/lít rượu; 5,0 UI/ lít rượu và 7,5 UI/lít rượu. Các dung dịch phản ứng được lắc đều với tốc độ 100 vòng/ phút, trong các khoảng thời gian 60,120 và 180 phút. Rượu vang được thăm đò độ hấp thụ ánh sáng sau đó đo độ truyền suốt ở bước sóng 520nm. Các nghiệm thức đối chứng được thực hiện trong cùng điều kiện với chế phẩm pectinase đã bị bất hoạt bằng cách đun cách thủy 15 phút. Độ truyền suốt $\mathrm{T}(\%)=1 / 10^{\mathrm{A}}$; với $\mathrm{A}$ là độ hấp thụ ánh sáng ở bước sóng 520nm. Độ truyền suốt gia tăng được tính bằng độ truyền suốt của các nghiệm thức trừ cho độ truyền suốt của nghiệm thức đối chứng tương ứng.

\section{Kết quả}

\section{1. Đánh giá hàm lự̣ng một số thành phần sinh hóa của vỏ trái cà phê}

Lớp vỏ chiếm đến $41,6 \%$ trong trái cà phê chín. Đây là nguồn nguyên liệu giàu đường và các chất dinh dưỡng khác. Kết quả kiểm tra một số thành phần sinh hóa trong lớp vỏ và dịch nhớt được thể hiện trong bảng 3 .

Bảng 3. Một số chỉ tiêu sinh hóa trong lớp vỏ và lớp nhớt của trái cà phê

\begin{tabular}{|l|c|c|}
\hline Thành phần sinh hóa & Lớp vỏ trái & Lớp nhó́t \\
\hline Nitơ tổng số $(\mathrm{g} / \mathrm{kg})$ & $13,50 \pm 0,90$ & $2,50 \pm 0,20$ \\
\hline Đường khử $(\%)$ & $2,57 \pm 0,17$ & $0,41 \pm 0,02$ \\
\hline Pectin $(\%)$ & $1,60 \pm 2,10$ & $7,94 \pm 0,20$ \\
\hline Độ ẩm $(\%)$ & $76,00 \pm 0,60$ & - \\
\hline $\mathrm{pH}_{\mathrm{H} 2 \mathrm{O}}$ & $5,2 \pm 0$ & $4,7 \pm 0,1$ \\
\hline
\end{tabular}

Quá trình chế biến cà phê theo phương pháp ướt thải bỏ nhiều thành phần của trái như lớp vỏ và lớp nhớt. Những phế liệu này có chứa một số chất dinh dưỡng như đạm, 
đường khử, pectin với hàm lượng nhất định, trong đó, hàm lượng pectin trong lớp nhớt lên đến $7,94 \%$. Trong khi đó, dịch nhớt từ quy trình chế biến cà phê theo phương pháp ướt đến nay vẫn chưa có biện pháp tận dụng, dung dịch pectin với độ nhớt cao là thành phần khó phân hủy sẽ làm gia tăng chi phí xử lý môi trường của các nhà máy. Dịch thải giàu pectin này có thể được tận dụng để tách chiết pectin sử dụng trong lãnh vực thực phẩm hoặc cảm ứng các chủng vi sinh vật sản xuất enzyme pectinase. Lớp vỏ trái với hàm lượng đạm và đường khử cao sẽ thuận lợi cho việc nuôi cấy thu sinh khối các chủng vi sinh vật.

\section{2. Định tính khả năng sinh pectinase của các chủng vi sinh}

Các chủng Bacillus sp. và Aspergillus niger được cấy lên các môi trường định tính, sau khoảng thời gian 3 ngày, xác định đường kính vòng phân giải pectin với thuốc thử lugon. Kết quả được thể hiện trong hình 1:

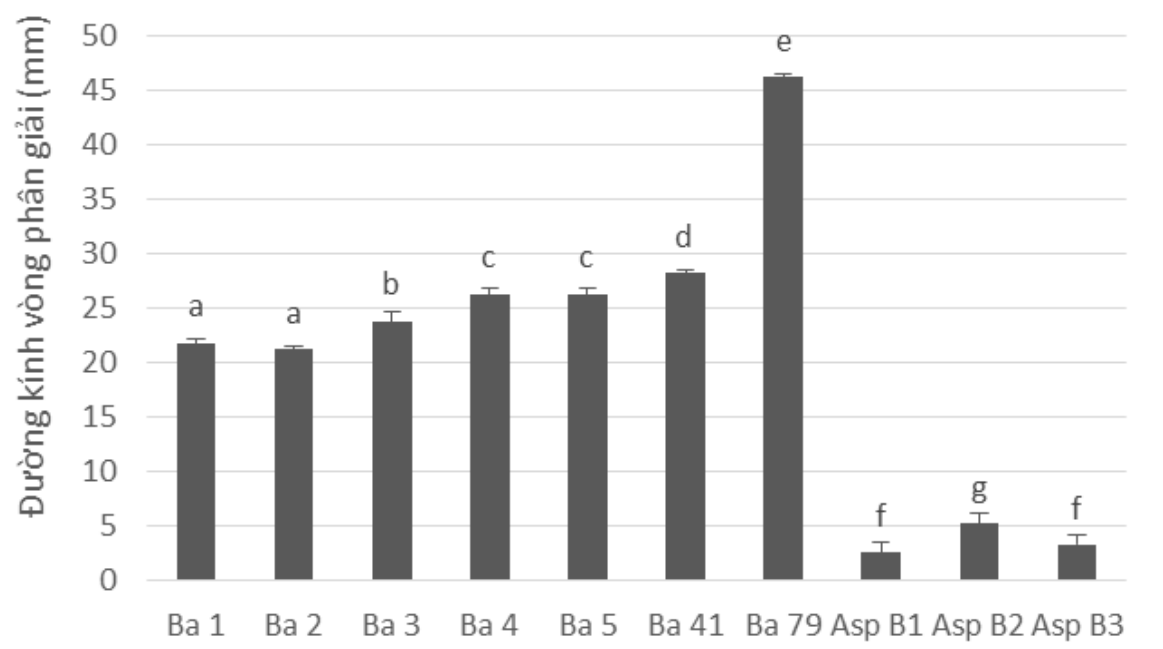

Chủng vi sinh vật

Hình 1: biểu đồ thể hiện đường kính vòng phân giải pectin của các chủng vi sinh vật.

Các kí tụ trên các cột biểu thị mức độ sai khác ở độ tin cậy 95\% (P<0,05).

Hầu hết các chủng vi khuẩn và nấm sử dụng trong nghiên cứu đều có khả năng sinh enzyme pectinase. Pectinase từ Bacillus sp. có hoạt tính mạnh và khuếch tán tốt trong môi trường thạch. Sau 3 ngày, đường kính vòng phân giải pectin của các chủng đạt từ $21-46 \mathrm{~mm}$. Chủng Bacillus $\mathrm{Ba} 79$ có vòng phân giải cao vượt trội so với các chủng còn lại, đạt $46 \mathrm{~mm}$. Trong khi đó, mặc dù các chủng Aspergillus niger có thể phát triển tốt trên môi trường định tính, nhưng lượng enzyme pectinase sinh ra không nhiều và không khuếch tán xa trong môi trường, vòng phân giải pectin gần sát mép với vòng tăng trưởng của nấm, đạt trung bình từ $1,3-1,7 \mathrm{~mm}$, riêng chủng Asp Đ3 có đường kính vòng phân giải lớn nhất, đạt trung bình $6,7 \mathrm{~mm}$ sau 3 ngày ủ. Từ kết quả trên, chúng tôi chọn các chủng $\mathrm{Ba} 79$ và chủng $\mathrm{Asp}$ Đ3 để thử nghiệm khả năng cảm ứng sinh pectinase trên môi trường bán rắn. 


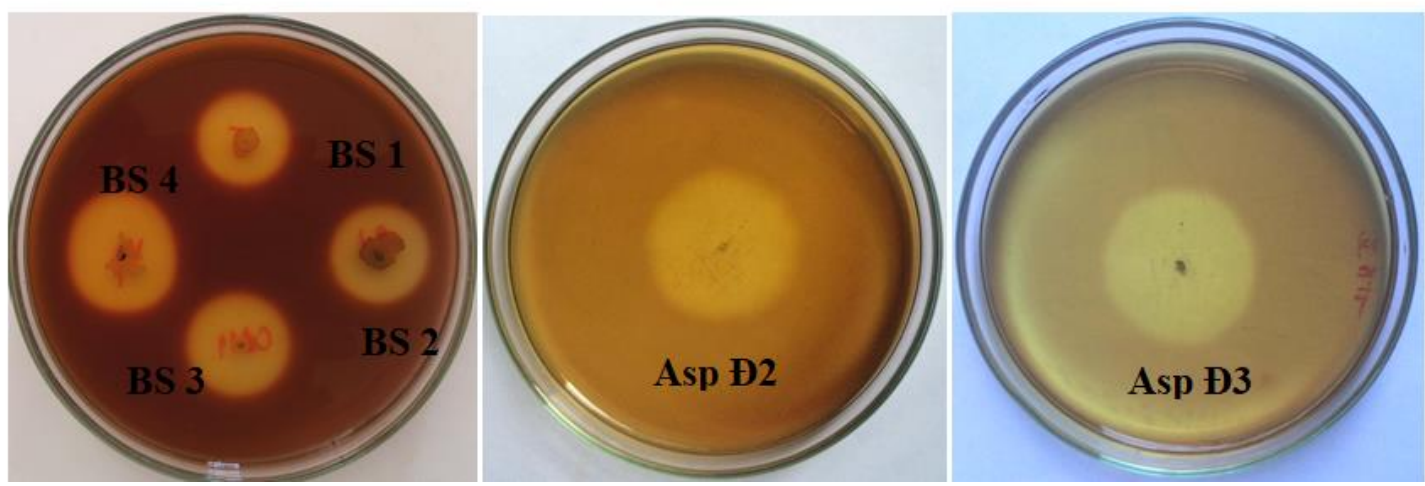

Hình 2. Đường kính vòng phân giải pectin của các chủng vi sinh trên môi trường thạch đĩa.

\subsection{Khả năng cảm úng nấm Aspergillus niger sinh pectinase của vỏ cà phê khô}

Chủng Asp Đ3 được cấy vào các môi trường bán rắn có chứa vỏ cà phê với thành phần thay đổi từ 5 đến $25 \%$. Sau 5 ngày ủ ở nhiệt độ phòng, xác định hoạt tính pectinase trong canh trường. Kết quả được thể hiện trong hình 3.

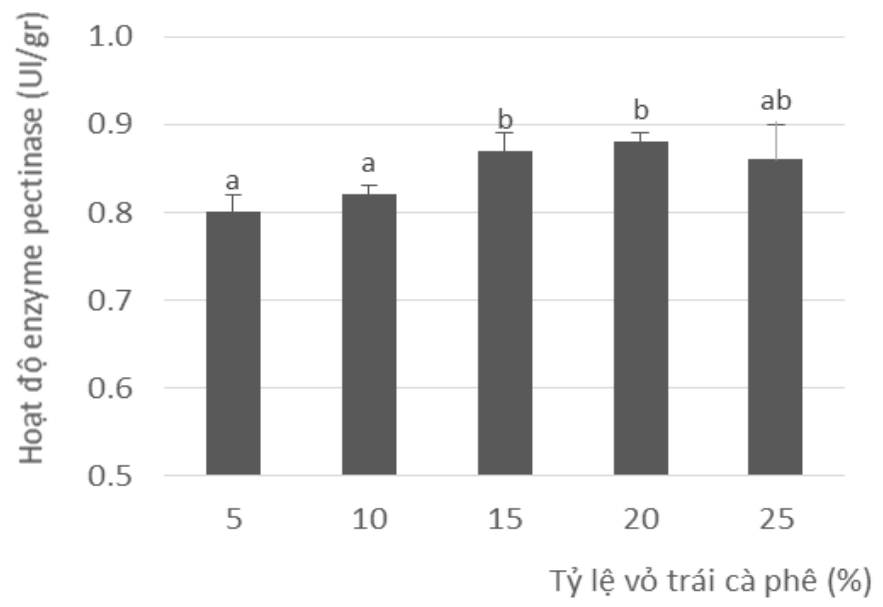

Hình 3: Ảnh hương của tỷ lệ vỏ cà phê đến khả năng cảm ưng sinh pectinase trên Asp Đ3.

Các kí tự trên các cột biểu thị mức độ sai khác ở độ tin cậy $95 \%(P<0,05)$.

Hàm lượng pectin trong vỏ cà phê không ảnh hưởng nhiều đến khả năng sinh tổng hợp pectinase của chủng nghiên cứu, hoạt độ dao động trong khoảng 0,80 - 0,88 UI/g. Hiệu quả thu nhận enzyme pectinase tốt nhất khi nuôi cấy trên môi trường chứa $20 \%$ vỏ cà phê và $35 \%$ cám gạo. Tuy nhiên, phương án tận dụng thành phần pectin có trong vỏ cà phê để nuôi cấy nấm Aspergillus niger thu nhận pectinase không đem lại hiệu quả kinh tế cao, hoạt độ pectinase thu được trong canh trường thấp hơn khi so với nuôi cấy trên các loại cơ chất khác như bã cà rốt, cùi bưởi... Trong quá trình nghiên cứu, chúng tôi cũng thử nghiệm nuôi cấy các chủng Bacillus Ba 79 trên các loại môi trường có chứa vỏ cà phê, mặc dù các chủng vi khuẩn này phát triển mạnh nhưng khả năng sinh pectinase rất yếu. Có thể do hàm lượng dinh dưỡng trong vỏ cà phê cao nên chúng không ưu tiên tổng hợp pectinase. 


\subsection{Khả năng cảm úng Bacillus Ba 79 sinh pectinase của lớp nhớt trái cà phê}

Chủng Bacillus $\mathrm{Ba} 79$ được cấy từ môi trường tăng sinh vào các môi trường bán rắn có chứa $60 \%$ dịch từ lớp nhớt của trái cà phê. Sau $3 ; 4$ và 5 ngày ủ ở nhiệt độ phòng, xác định hoạt tính pectinase trong canh trường. Kết quả được thể hiện trong bảng 4 và biểu đồ 3 .

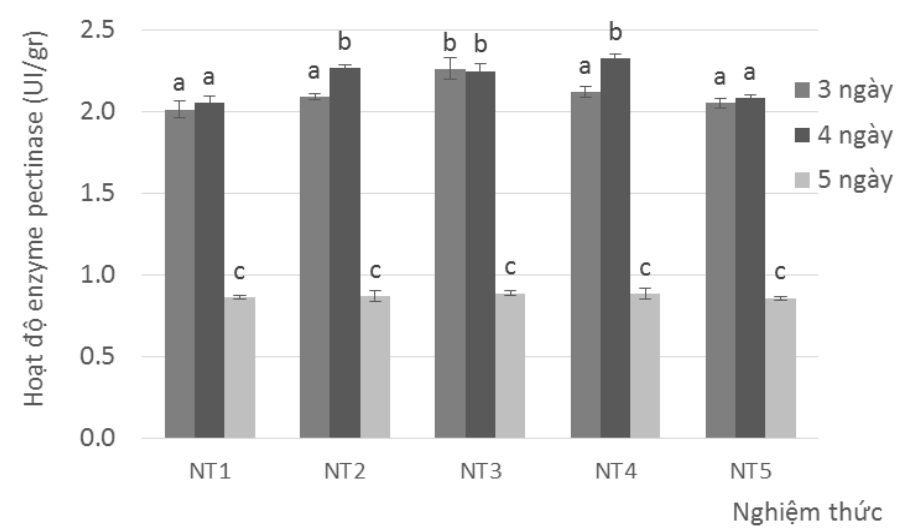

Hình 4. Khả năng cảm ứng sinh pectinase tù Bacillus Ba 79 của lớp nhớt trái cà phê trên các loại môi trường và thời gian nuôi cấy khác nhau. Các kí tư trên các cột biểu thị mức độ sai khác ở độ tin cậy $95 \%(P<0,05)$.

Thành phần pectin trong lớp nhớt của trái cà phê có khả năng cảm ứng chủng Bacillus Ba 79 sinh pectinase tốt, hoạt độ enzyme dao động trong khoảng 2,01 - 2,26 UI/g sau 3 ngày nuôi cấy. Hoạt độ pectinase trong các canh trường đạt cực đại ở ngày thứ tư sau đó giảm mạnh, dao động trong khoảng 0,86 - 0,89 UI/g. Pectin trong lớp nhớt của trái cà phê cảm ứng sinh enzyme pectinase tốt nhất khi nuôi cấy chủng $\mathrm{Ba} 79$ trên môi trường chứa cơ chất là $16 \%$ bắp và $24 \%$ bã đậu nành, hoạt độ pectinase sau 4 ngày nuôi cấy đạt $2,33 \mathrm{UI} / \mathrm{g}$, khác biệt có ý nghĩa thống kê ở độ tin cây $95 \%$ so với các nghiệm thức và thời gian nuôi cấy khác.

Hầu hết các nghiên cứu nuôi về cấy thu nhận enzyme pectinase đều tập trung sử dụng các chủng Aspergillus niger trên các loại phế phụ liệu giàu pectin khác như cám mì, cùi bưởi, cùi vỏ cam, cùi vỏ chanh, vỏ xoài, vỏ chuối... hoạt độ enzyme tối ưu một số nghiên cứu công bố gần đây nằm trong khoảng 5,38 - 5,88 UI/ml (Trần Thị Thanh Thuần, 2009; Nguyễn Đức Lượng, 2010; Lê Thị Thu Trang, 2011). Rất ít có nghiên cứu sử dụng dịch lớp nhớt từ trái cà phê để cảm ứng sinh pectinase trên Bacillus. Những kết quả nghiên cứu ban đầu của chúng tôi cho thấy tận dụng dịch nhớt để nuôi cấy thu enzyme pectinase sẽ thu được chế phẩm có hoạt độ khá tốt. Ngoài ra, kết quả nghiên cứu còn góp phần nâng cao giá trị quá trình biến cà phê theo phương pháp ướt.

\subsection{Thử nghiệm làm trong rựu vang của chế phẩm pectinase}

Chế phẩm enzyme pectinase được bổ sung vào rượu vang có cặn ở các tỷ lệ 2,5; 5,0 và 7,5 UI/lít. Tác dụng gia tăng độ truyền suốt của chế phẩm được thể hiện trong hình 5 . 


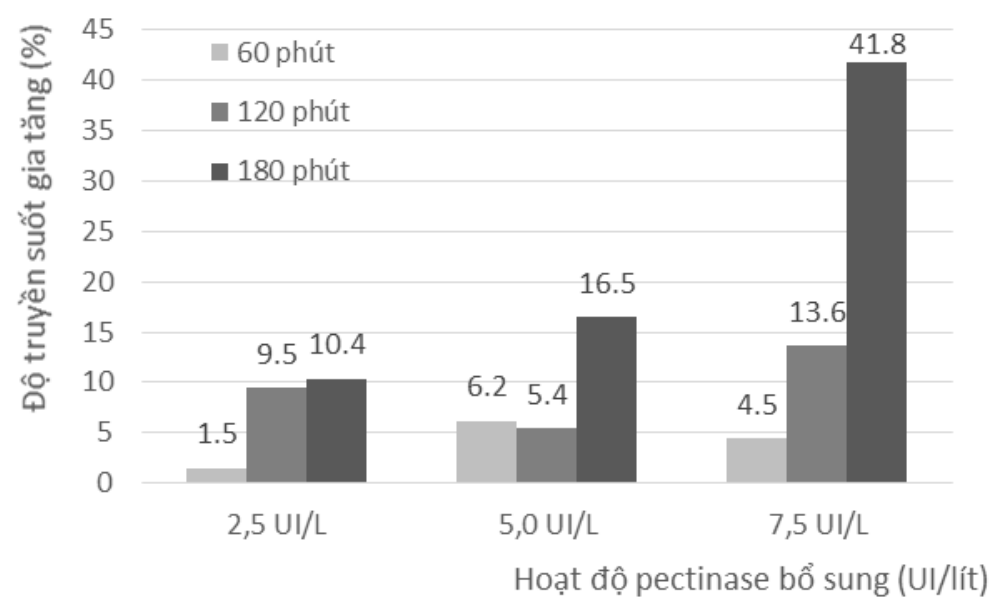

Hình 5. Khả năng làm tăng độ trong rươu vang của chế phẩm enzyme pectinase.

Các kí tụ trên các cột biểu thị mức độ sai khác ở độ tin cậy $95 \%(P<0,05)$.

Rượu vang sau 2 năm bảo quản ở nhiệt độ phòng sẽ lắng một lượng cặn đáng kể dưới đáy chai. Việc bổ sung enzyme pectinase từ vi khuẩn Bacillus Ba 79 đã cho thấy hiệu quả gia tăng độ trong của rượu. Thời gian càng lâu, hiệu quả thủy phân lớp cặn càng rõ rệt. Ở nghiệm thức xử lý 180 phút, lượng pectinase bổ sung ở tỷ lệ 5 UI và 7,5 UI cho hiệu quả rõ rệt hơn so với tỷ lệ 2,5 UI/lít, độ trong của rượu gia tăng lần lượt 16,5 và $41,8 \%$ so với đối chứng. Lớp cặn lắng của rượu vang bao gồm nhiều thành phần khác nhau như pectin, protein dạng sợi và các yếu tố không tan khác, kết quả của thí nghiệm bước đầu cho thấy hiệu quả làm tăng độ trong của rượu, việc phối hợp sử dụng với các chế phẩm enzyme khác có thể sẽ giúp nâng cao chất lượng cảm quan của rượu trong quá trình bảo quản.

\section{Kết luận}

Trên môi trường thạch đĩa, chủng Aspergillus Đ3 và Bacillus Ba 79 có đường kính vòng phân giải pectin lớn nhất, lần lượt đạt trung bình $6,7 \mathrm{~mm}$ và $46 \mathrm{~mm}$. Thành phần pectin trong vỏ cà phê có khả năng cảm ứng sinh Aspergillus niger Đ3 sinh enzyme pectinase, tuy nhiên, hiệu quả sinh tổng hợp của chủng không cao, hoạt độ chỉ đạt $0,88 \mathrm{UI} / \mathrm{g}$ trên môi trường có chứa $20 \%$ vỏ cà phê. Khả năng cảm ứng sinh pectinase ở Bacillus Ba 79 đem lại hiệu quả khá cao, hoạt độ enzyme đạt 2,33 UI/g sau 4 ngày nuôi cấy trên môi trường có chứa $60 \%$ dịch nhớt cà phê, $16 \%$ bắp xay và $24 \%$ bã đậu nành. Ở tỷ lệ bổ sung 7,5 UI/lít, thời gian xử lý 180 phút, chế phẩm pectinase có khả năng làm tăng độ trong của rượu vang 41,8\%.

Lòi cảm ơn : Xin chân thành cảm ơn sụ hỗ trợ kinh phí của Chuoong trình Sinh viên Nghiên cúu Khoa họ, Truờng Đại học Thủ Dầu Một và sự giúp đõ̃ của Trung tâm Nghiên cúu và Thực nghiệm truờng Đại học Thủ Dầu Một; xin cảm ơn sụ hỗ trọ̣ của sinh viên Nguyến Trường Nam - Khoa Tài nguyên Môi truờng đã hỗ trọ̣ trong một số công việc. 


\section{TÀI LIỆU THAM KHẢO}

[1] Lâm thị Kim Châu, Văn Đức Chín, Ngô Đại Nghiệp (2004). Thục tập lớn sinh hóa. NXB Đại học quốc gia TP Hồ Chí Minh.

[2] Nguyễn Văn Mùi (2007). Thưc hành Hóa sinh học. NXB Đại học Quốc gia Hà Nội.

[3] Trần Thị Thanh Thuần, Nguyễn Đức Lượng (2009). Nghiên cứu enzyme cellulase và pectinase từ chủng Trichoderma viride và Aspergillus niger nhằm xử lý nhanh vỏ cà phê. Tạp chí Phát triển Khoa học và Kã thuật, 12(3), tr. 50 - 56.

[4] Nguyễn Đức Lượng, Bùi Anh Võ (2010). Nghiên cứu thu nhận pectin từ vỏ cà phê. Tạp chí Phát triển Khoa họ và Công nghệ, 13(K2), tr. 46 - 55.

[5] Lê Thị Thu Trang (2011). Nghiên cứu khả năng tổng hợp pectiesterase và polygalacturonase của Aspergillus niger. Luận văn thạc sĩ kỹ thuật chuyên ngành công nghệ thực phẩm và đồ uống. Trường Đại học Đà Nẵng.

[6] Ashfaq K., Saniay S. and Neha R. (2012). Production and optimization of pectinase enzyme using Aspergillus niger in solid state fermentation. Research in Biotechnology, 3, page. 19-25.

[7] Tivkaa A., Bukola A. (2012). Screening of new isolates fungal strains for polygalacturolase production in submerged fermentation. Innovative Romanian Food Biotechnology, 11, Issue September, page 15-22.

[8] Ermias G., Teshome W. (2016). Extraction and characterization of pectin from selected fruit peel waste. International Journal of Scientific and Research Publications, 6(2), p. 447-454. 